\title{
CONCENTRATION OF NICKEL (NI) AND CHROMIUM (Cr) IN SEDIMENT AND SUSO SNAIL (Tylomelania patriarchalis) AT BOTTOM LAYER OF MATANO LAKE, SOUTH SULAWESI
}

\author{
Kamaluddin Kasim and Mas Tri Djoko Sunarno \\ Researcher in Research Center for Capture Fisheries-Ancol, Jakarta \\ Received May 6-2009; Received in revised from May 18-2009; Accepted May 28-2009
}

\begin{abstract}
Research on nickel ( $\mathrm{Ni}$ ) and chromium $(\mathrm{Cr})$ concentration in sediment and meat of suso snail (Tylomelania patriarchalis) collected from bottom layer of Lake Matano, South Sulawe il, was conducted on July-August 2004. Research station was established purposively according to a distance from source of industrial activities, namely station $A(25 \mathrm{~km})$, station $B(14 \mathrm{~km})$, station $C(5 \mathrm{~km})$, and station $\mathrm{D}(7 \mathrm{~km})$, respectively. These stations had a difference distance of about $50 \mathrm{~m}$ from off-shore of the lake. Each station was divided by three substation having 75-100 $\mathrm{m}$ in distance. Samples of sediment and suso snail were collected at the station using Eickman Grab. The samples were kept in labelled plastic bag and then put in cool box at $4^{\circ} \mathrm{C}$ as a subject to observing in laboratorium. Concentrations of $\mathrm{Ni}$ and $\mathrm{Cr}$ were measured using Atomic Absorption Spectrofotometry method. The results showed that the highest $\mathrm{Ni}$ concentration in sediment was observed in station $\mathrm{C}(5,277.5 \mathrm{mg} / \mathrm{kg})$ and significantly difference $(p<0.01)$ to other sampling stations. Concentration of $\mathrm{Cr}$ was not significance in each station. The highest concentration of the metals in the snail was observed in station $C(0.56$ $\mathrm{mg} / \mathrm{kg})$ for $\mathrm{Cr}$ and in station $\mathrm{B}(293.84 \mathrm{mg} / \mathrm{kg})$ for $\mathrm{Ni}$.
\end{abstract}

KEYWORDS: nickel, chromium, sediment, suso snail, Tylomelania patriarchalis, Matano Lake

\section{INTRODUCTION}

One of area in Matano Lake surrounding-Soroako City, South Sulawesi, has been used as the biggest nickel mining activity in Indonesia. Mining involves a series of land digging and destroying activities, respectively to explore minerals content using a material containing heavy metal. Waste of these activities is a slurry containing heavy metals. During rainy season particularly, water run off will bring the waste into the waters of Lake Matano and might affect the environment surrounding the mining activities.

Palar (1994) stated that heavy metals in the waters would sediment through particle binding processes and accumulate in the bottom layer of the waters. Therefore, concentration of the heavy metals in the bottom layer was higher than that in the water body as well as the aquatic organism.

Bentos organisms living in the bottom layer of the waters can be used as a biological indicator for water pollution of rivers as well as lake. Suso snail (Tylomelania patriarchalis) is one of macrozoobentos organism which is abundance in Matano Lake and consumed by the peoples surrounding of the lake. Therefore, data of heavy metals concentration at the bottom layer of the waters having mining activities is required to determine a status of water pollution, but there is a limit information in Matano Lake.
Nickel (Ni) endangers to human health. Direct contact of Ni salts solution to human skin could affect dermatitis, whilst breathing Ni affects on lung cancer (Effendie, 2000). According to Sudarmaji et al. (2006), chromium $(\mathrm{Cr})$ could worst affect on respiratory tract, skin, blood vessel, and knee.

Nickel of 237 and $301 \mathrm{mg} / \mathrm{L}$ gives death effect on larvae and embryo of mussels, respectively. Eisler (1998) reported that total death of fresh water snail and mollusc embryos were at a level of 237 dan 301 $\mathrm{mg} / \mathrm{L}$, respectively. Value of $L_{50}$ for fresh water snail Juga plicifera was $237 \mathrm{mg} \mathrm{Ni} / \mathrm{L}$ for 96 exposure hours, whilst mollusc adult of Mya arenaria has $\mathrm{LC}_{50}$ at 112 $\mathrm{mg} \mathrm{Ni/L}$ for 168 exposure hours. Chromium also affect on lethal death for some aquatics animal. Vutukuru (2005) stated that $L_{50}$ for Labeo rohita was $39.4 \mathrm{mg}$ $\mathrm{Cr} / \mathrm{L}$ for 96 exposure hours.

It had been approved that $\mathrm{Ni}$ and $\mathrm{Cr}$ in waters would be deposited in bottom layer of the waters. Therefore, a research was done for observing $\mathrm{Ni}$ and $\mathrm{Cr}$ concentration on sediment and suso snail at the bottom layer of Lake Matano, So th Sulawesi.

\section{MATERIALS AND METHODS}

The research was conducted or ily-August 2004 in Matano Lake, South Sulawesi. Some stations were established proposively in 4 places with a distance of $50 \mathrm{~m}$ from offshore of the lake. Determination of the 


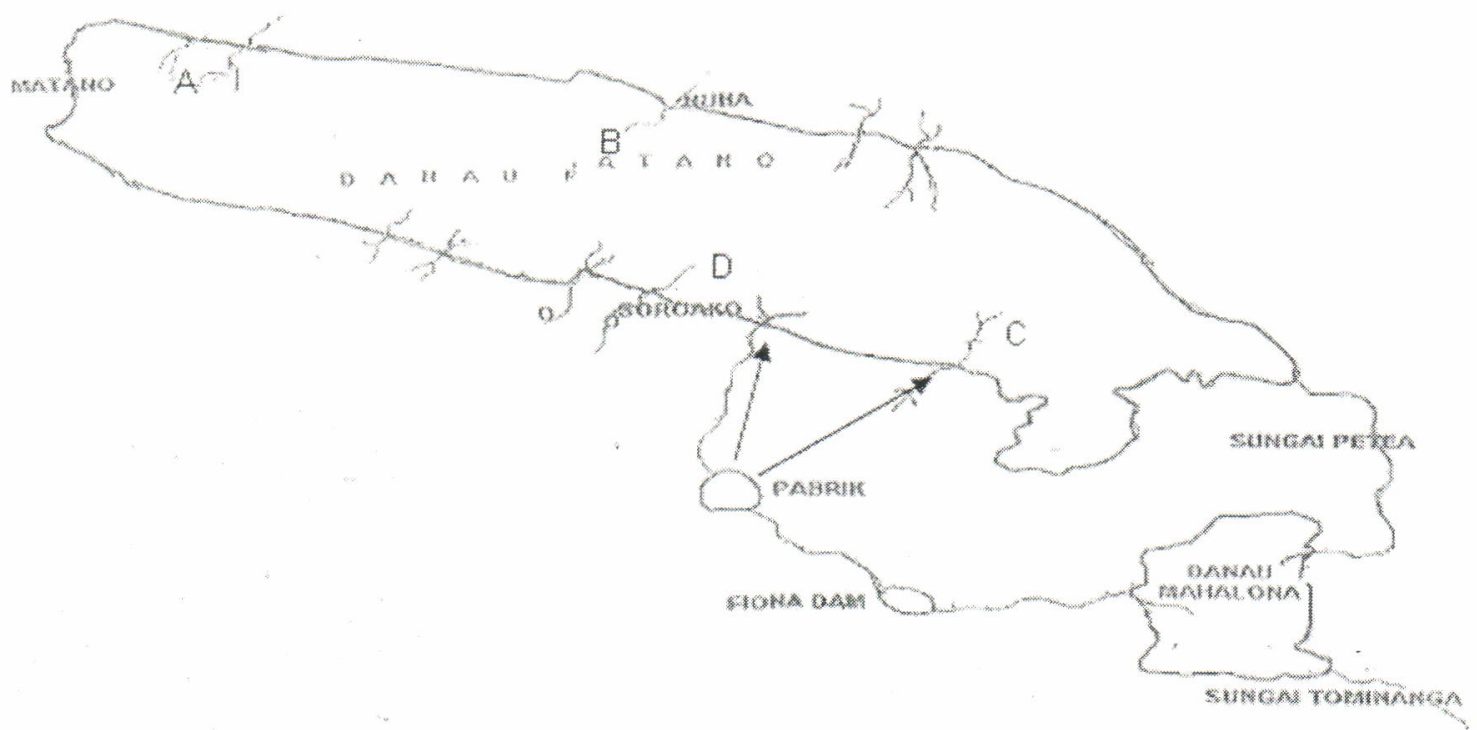

Figure 1. Sampling site used in the research.

Remarks: $\longrightarrow$ Water Iniet to Matano Lake; $A=$ station with $25 \mathrm{~km}$ distance from nickel processing plan; $\mathrm{B}=$ station $\mathrm{B}$ with $14 \mathrm{~km}$ distance from nickel processing plan; $\mathrm{C}=$ station $\mathrm{C}$ with $5 \mathrm{~km}$ distance from nickel processing plan; $\mathrm{D}=$ station $\mathrm{D}$ with $7 \mathrm{~km}$ distance from nickel processing plan

station was based on distance of a source of mining activity, namely station A (25 km), station B (14 km), station $C(5 \mathrm{~km})$, and station $D(7 \mathrm{~km})$ respectively. Each station was divided by three substation having 75-100 $\mathrm{m}$ in distance (Figure 1).

In each station, samples of sediment and suso snail were collected using Eickman Grab at 1-5 m water depth according to availability of snail. The mud and snail was separated using hand, kept in labeled plastic bag and then hold in cool box at a temperature level of $4^{\circ} \mathrm{C}$. Only 12 snails were taken from each station as a subject to laboratory analysis.

Sediment was dried using room temperature for 48 hours in the laboratory. There after, dried sediment was sieved using sieve net of $0.125 \mathrm{~mm}$ in diameter and taken out in amount of $2 \mathrm{~g}$ as a subject to heavy metal analysis. The sediment sample was diluted using nitrat acid $65 \%$ and heated using hot plate at temperature range of $70-80^{\circ} \mathrm{C}$, then the diluted samples was dried and ready to be analyzed using Atomic Adsorption Spectrofotometry Perkin Elmer Analyst 7,000. Each sample was analyzed with 3 replicates (APHA, 1980).

Data was analyzed statistically using KruskallWallis and Mann-Whitney test for evaluating differences of nickel and chromium concentration. The SPSS program version 15 was used to analyze the data. Analysis of regression was used to know a relationship between nickel and chromium concentration in sediment and suso snail. Model of regression is:

$$
Y=a+b X
$$

where:

$$
\begin{aligned}
Y= & \text { concentration of nickel or cromium in suso } \\
& \text { snail }(\mathrm{mg} / \mathrm{kg}) \\
X= & \text { concentration of nickel or cromium in } \\
& \text { sediment }(\mathrm{mg} / \mathrm{kg}) \\
\mathrm{a}= & \text { intercept } \\
\mathrm{b}= & \text { slope }
\end{aligned}
$$

\section{RESULTS AND DISCUSSION}

The data showed that the concentration of nickel in each sampling station was relatively high (Figure 2). The highest concentration was $5,277.5 \mathrm{mg} / \mathrm{kg}$ found in station C-relatively close to the nickel processing plant $( \pm 5 \mathrm{~km})$. The lowest nickel concentration was found in station A which was $2,009.83 \mathrm{mg} / \mathrm{kg}$. Station A was the furthest located $25 \mathrm{~km}$ away from nickel processing plant. The highest nickel concentration in station $\mathrm{C}$ might be caused by it location near from mine activities such as open mining soil and processing plant. It caused run-off sediment entering to the Matano Lake water column marked by yellow brown sediment colors likely found in station C.

Land clearing in mine activity at Matano Lake surrounding caused run-off entering to the Matano Lake waters during rainy season. Connel \& Miller (1984) 
stated that open mining activities leaving the soil surface exposed could cause soil and rock decaying process rapidly and carrying some minerals and metais in water column.

Haffner (2000) in his latest investigation stated that nickel concentration in sediment at Lake Matano varied from 12,000-30,000 mg/kg. Moore (1991) in Effendie (2000) stated that nickel concentration naturally found in soil about $75 \mathrm{mg} / \mathrm{kg}$. Moreover, Cataldo \& Wildug (1978) stated that nickel concentration naturally found in soil varied from $10-1,000 \mathrm{ig} / \mathrm{g}$

Nickel concentration in sediment was high at sampling station $D$, located about $7 \mathrm{~km}$ from nickel processing plant and mining area. Average of nickel concentration in sediment found in station D was high, up to $3,681,25 \mathrm{mg} / \mathrm{kg}$. As close to the nickel processing plant, the station received more waste. That was proved by waste concentration in inlet locating in station D (Figure 1). The Kruskall-Wallis test showed that nickel concentration in sediment at each sampling station was significantly different $(p<0.01)$. It meant that sampling station $C$ and $D$ were the most receiving nickel waste from processing plant and mining area whilst sampling station $A$ and $B$ were less.

Nickel concentration in suso meat at each sampling station was relatively high (Figure 3 ). The highest average nickel concentration was observed at station B $(293.84 \mathrm{mg} / \mathrm{kg})$ and the lowest was at station C $(50.813 \mathrm{mg} / \mathrm{kg})$. The Kruskall-Wallis test inter-sampling station showed that average nickel

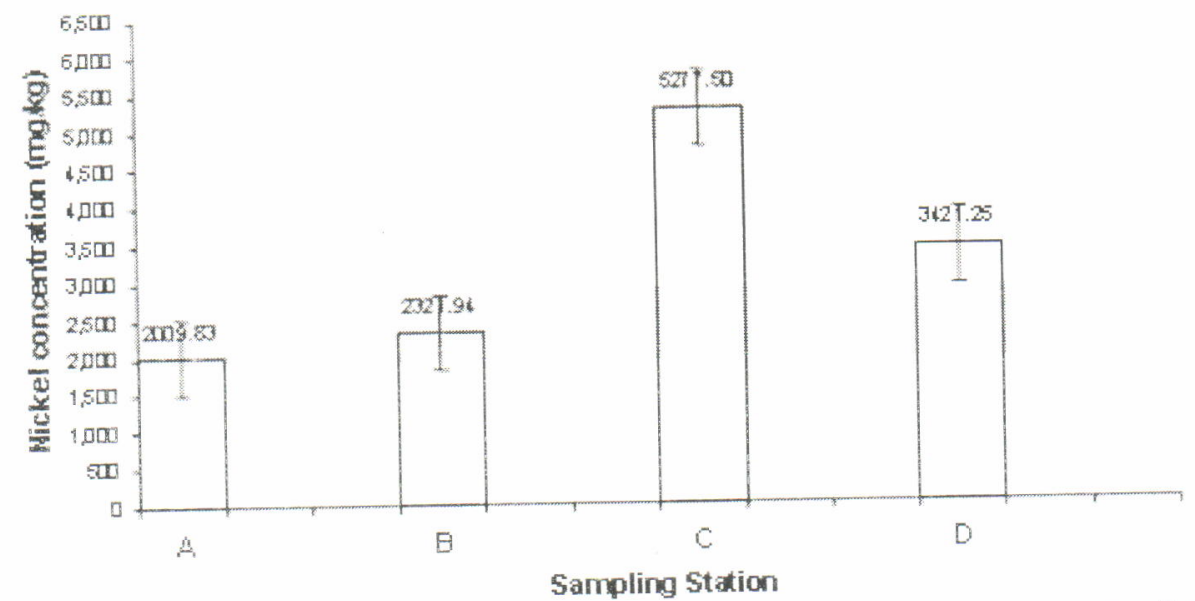

$A=$ station $A$ with $25 \mathrm{~km}$ distance from nickel processing plan; $B=$ station $B$ with $14 \mathrm{~km}$ distance from nickel processing plan; $C=$ station $C$ with $5 \mathrm{~km}$ distance from nickel processing plan; $D=$ station $D$ with $7 \mathrm{~km}$ distance from nickel processing plan

Figure 2. Average nickel concentration of sediment in each sampling station.

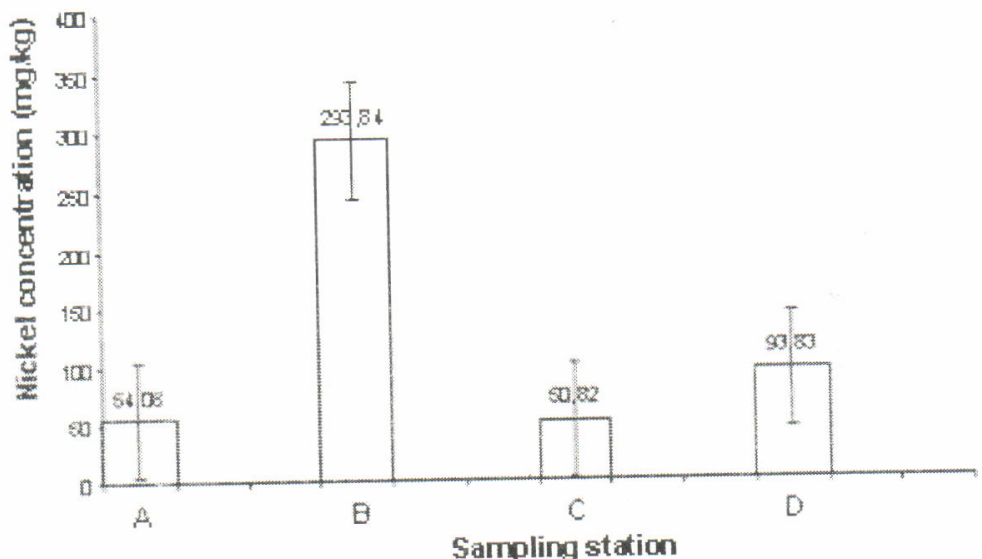

$A=$ station $A$ with $25 \mathrm{~km}$ distance from nickel processing plan; $B=$ station $B$ with $14 \mathrm{~km}$ distance from nickel processing plan; $C=$ station $C$ with $5 \mathrm{~km}$ distance from nickel processing plan; $D=$ station $D$ with $7 \mathrm{~km}$ distance from nickel processing plan

Figure 3. Average nickel concentration of suso snail in each sampling station 
average of chromium concentration in suso snail was significantly difference $(p<0.05)$.

Station $\mathrm{C}$ is one of sampling station close to the nickel processing plant. The highest chromium concentration in suso snail meat at Station $\mathrm{C}$ was probably influenced by chromium concentration in sediment. Chromium concentration in sediment was nearly similar at each sampling station, except in suso snail. Kruskall-Walis test showed that chromium concentration in suso snail was very significantly difference $(p<0.01)$ in each sampling station. This also may indicate that suso snail has a different ability in absorbing metal

Regression analyze showed that chromium concentration in suso snail was linear and positive following the equation $Y=0.0883 X-0.1981$, where $Y=$ chromium concentration in suso snail, and $X=$ chromium concentration in sediment. $R^{2}$ is 0.5807 whilst coefficient correlation ( $r$ ) is 0.7620 (Figure 7).

High concentration of chromium at each sampling station indicated that suso snail was not properly consurined. WHO (2000) determined that chromium concentration in food is not exceed the threshold limit $0.05 \mathrm{mg} / \mathrm{kg}$.

\section{CONCLUSION}

1. The highest $\mathrm{Ni}$ concentration in sediment was observed in station $C(5,277.5 \mathrm{mg} / \mathrm{kg})$ and significantly difference $(p<0.01)$ to other sampling stations. Concentration of $\mathrm{Cr}$ was not significance in each station. The highest concentration of the metals in the snail was observed in station $\mathrm{C}(0.56$ $\mathrm{mg} / \mathrm{kg}$ ) for $\mathrm{Cr}$ and in station B (293.84 mg/kg) for $\mathrm{Ni}$.

2. Concentration value of nickel and chromium in suso snail (Tylomelania patriarchalis) in Matano Lake was lower than in sediment. There is positive correlation between nickel and chromium concentration in sediment and suso snail (Tylomelania patriarchalis)

\section{ACKNOWLEDEMENT}

This research was budgeted by individual funding. I would like to thank to the head and staffs of Laboratorium Dinas Perindustrian dan Perdagangan Provinsi Sulawesi Selatan who help us to analyze material samples.

\section{REFERENCES}

APHA. 1980. Standard Methods for the Examination of Water And Wastewater. APHA, AWWA, WPCF $17^{\text {th }}$ eds. Washington D. C

Cataldo, D. A. \& R. E. Wildug. 1978. Soil and plant factors influencing the accumulation of heavy metals by plants. Environmental Perspective 2007. 27: 149-159

Connel, D. W. \& G. J. Miller. 1984. Chemistry and Ecotoxicology of Pollution. Wiley-Interscience

Eisler, R. 1998. Nickel hazards to fish, wildlife, and ivertebrates: A sinoptic review. Contaminant Hazard Reviews Report No.34. Patuxent Wildlife Research Center. U. S. Geological Survey, Laurel. U.S.A "http://www.pwrc.usgs.gov/infobase/eisler/chr_34 nickel.pdf". Accessed at 12 March 2009.

Effendie, H. 2000. Telaahan Kualitas Air. Modull Kuliah Jurusan Manajemen Sumber Daya Perairan. Fakultas Perikanan dan IImu Kelautàn. Institut Pertanian Bogor. Bogor.

Fishbein, L. 1981. Sources, transport, and alteration of metal compounds: An overview. I Arsenic, Beryllium, Cadmium, Chromium, and Nickel. Environmental Health Perspectives. Department of Healt, Education and Welfare, Food and Drug Administration, National Center for Toxicologycal Research, Arkansas. USA. 40: 43-64

Haffner, D. 2000. Studies in Malili Lakes. Great Lakes Institute for Environmental Research. Windsor. Ontario. Canada.

Palar, H. 1994. Pencemaran dan Toksikologi Logam Berat. Rineka Cipta. Jakarta.

Sudarmadji, J. Mukono, \& I. P. Corie. 2006. Toksikologi Logam Berat B3 dan Dampaknya Terhadap Kesehatan. Bagian Kesehatan Lingkungan. Fakultas Kesehatan Masyarakat. Universitas Airlangga. Surabaya

Tack, F. M. \& M. G. Verloo. 1995. Chemical speciation and fractionation in soil and sediment heavy metal analysis: A review. International Journal of Environmental Analytical Chemistry. 59: 225-238. 
Umar, T., W. M. Meagaung, \& L. Fachruddin. 2001 Kandungan Logam Berat Tembaga (Cu) pada Air, Sedimen, dan Kerang Marcia sp. di Perairan Teluk Pare-Pare Sulawesi Selatan. Fakultas IImu Kelautan dan Perikanan. Universitas Hasanuddin. Makassar.

Vutukuru, S. S. 2005. Acute effects of hexavalent chromium on survival, oxygen consumption, hematological parameters and some biochemical profiles of the Indian Major Carp, Labeo rohita. International Journal of Environmental Research and Public Health ISSN 1660-4601. 456-462.

WHO. 2000. General Office for Europe. Nickel. Copenhagen. Denmark. http://www.euro.who.int/ document/aiq/

6_10nickel.pdf. accessed 17 march 09 
